\title{
ANALISIS FAKTOR-FAKTOR YANG MEMPENGARUHI KEPUTUSAN KONSUMEN ATAU NASABAH DALAM MEMILIH BANK SEBAGAI TEMPAT MENABUNG DI YOGYAKARTA
}

\author{
Galih Widhiyanto \\ galih_widhiyanto@yahoo.com \\ Universitas Ahmad Dahlan \\ Hendro Setyono \\ hendro.setyono@yahoo.com \\ Universitas Ahmad Dahlan
}

\begin{abstract}
ABSTRAK
This study aims to determine the effect of multipurpose networks ATMs, interest, administrative fees, bank locations and bank services the customer's decision in choosing a bank as a place to save in Yogyakarta. In this study, taking a sample of residents who live in the city Yogyakarta with 60 respondents. This testing using analysis tools in the form of correlation (validity test) and reliability test for know the validity of the data used in research. To test the hypothesis in this research is multiple regression test. In the F test obtained F count (27.594)> F table (2.28) which means that together there is a significant influence between the variable services, bank locations, multipurpose ATM networks, bank interest and administrative fees towards decisions. In the $t$ test there are three variables that have no effect significantly to customer savings decisions, namely service variables with a value of $t$ arithmetic (1.385) <t table (2.0057), Bank Location with a value of $t$ arithmetic $(1,933)<t$ table (2.0057) and Multipurpose And ATM Networks with calculated t values $(0.839)<\mathrm{t}$ table (2.0057). While interest and administrative costs are partial each has a significant effect on the savings decision variable customers because the $t$ value obtained for the bank interest $(3,697)>t$ table $(2.0057)$ and administrative costs $(3,510)>t$ table $(2.0057)$. The results of this study provide evidence that $71.9 \%$ of customers' savings decisions influenced by the variable service, bank location, multipurpose ATM networks, bank interest and administrative costs while the remaining $28.1 \%$ influenced by other factors. Based on data analysis, the factors are a big influence on customer savings decisions is bank interest.
\end{abstract}

Keywords: Multipurpose ATM Network, Bank Interest, Administrative Fees, Bank Location, Bank Services and Customer Decision.

\begin{tabular}{l}
\hline PENDAHULUAN \\
Perkembangan peran perbankan di \\
Indonesia tidak pernah terlepas dari sistem \\
perbankan di Indonesia secara umum. \\
Sebagaimana yang telah diatur dalam UU \\
No.10 tahun 1998 di mana bank umum \\
adalah bank yang melaksanakan kegiatan \\
usaha secara konvensional atau \\
berdasarkan prinsip syariah yang \\
kegiatannya memberikan jasa dalam lalu \\
lintas pembayaran. Peran bank, baik itu
\end{tabular}

bank konvensional maupun bank syariah sangat strategis untuk mewujudkan struktur perekonomian yang semakin berimbang.

Banyaknya perusahaan perbankan dengan berbagai macam produk dan keunggulan yang ditawarkan menimbulkan sebuah kebingungan tersendiri bagi calon nasabah untuk menentukan tempat menabung. Pemahaman dan sosialisasi terhadap masyarakat tentang produk dan sistem perbankan di Indonesia juga masih 
sangat terbatas. Maka dalam situasi yang komplek seperti ini diperlukan suatu pemikiran yang mendalam dan sistematis sebelum pengambilan keputusan. Kriteriakriteria dan keunggulan produk yang ditawarkan oleh pihak bank, merupakan suatu alat pertimbangan nasabah untuk membuka tabungan. Akan tetapi tanpa adanya data dan informasi yang kuantitatif sebagai penunjang proses pemilihan tempat untuk membuka tabungan di bank, pemilihan akan menjadi tidak obyektif dan kemungkinan akan terjadi kekeliruan. Dan apabila sudah terjadi kekeliruan, maka akan mengakibatkan kerugian, baik bagi pihak bank maupun pihak nasabah.

Bisnis perbankan merupakan bisnis jasa yang mengutamakan kepercayaan sehingga masalah kualitas layanan menjadi faktor yang sangat menentukan dalam keberhasilan usaha ini. Persaingan antar bank untuk menarik nasabah sebanyakbanyaknya, memaksa setiap bank untuk menciptakan berbagai produk perbankan yang unggul dan menguntungkan. Berbagai produk yang biasanya di tawarkan bank kepada masyarakat adalah tabungan, deposito dan giro. Tabungan sebagai komponen utama pengumpul dana pihak ketiga merupakan produk perbankan yang paling sering menjadi fokus perhatian para pelaku perbankan.

Berbagai upaya dilakukan oleh pelaku perbankan untuk menarik nasabah, dari mulai promosi, pemberian bunga, biaya administrasi yang kecil, keamanan simpanan, dan juga pelayanan yang memuaskan. Akan tetapi, tingkat kepuasan nasabah berbeda-beda, karena dipengaruhi oleh ekpektasi masing-masing individu terhadap suatu produk, apakah sesuai dengan yang diharapkan ataukah tidak memenuhi harapannya. Jadi, seorang pelanggan yang puas adalah pelanggan yang merasa mendapatkan nilai keunggulan dari produsen atau penyedia jasa. Nilai keunggulan berasal dari produk, pelayanan, sistem dan sesuatu yang bersifat emosional.
Betapa pentingnya untuk meningkatkan mutu dan pelayanan bank secara efektif, sesuai dengan keadaan perekonomian dan kebutuhan para nasabah. Untuk itu diperlukan sebuah analisis mengenai pemilihan bank oleh para nasabah sebagai tempat menabung. Di harapkan dengan adanya analisis ini, para nasabah akan mengambil keputusan yang logis dan efektif mengenai pemilihan tempat menabung di bank yang sesuai dengan prioritas dan kebutuhan. Penelitian ini menitikberatkan pada analisis pemilihan bank sebagai tempat menabung dengan melakukan perbandingan antar preferensi dari faktor-faktor yang mempengaruhi pemilihan tempat menabung. Datadata penelitian diperoleh dari bank yang dinilai memiliki keunggulan, diantaranya yaitu Bank Mandiri, BNI, BCA, BRI, Bank Danamon, serta BPD DIY maupun BPR. Untuk satu jenis tabungan yang paling umum dari masing-masing bank yang di teliti. Pengambilan data kuantitatif berupa penyebaran kuisioner dibatasi pada wilayah Kotamadya Yogyakarta.

Tujuan dari penelitian ini di antaranya: 1) untuk menganalisis pengaruh variabel multiguna dan jaringan ATM, bunga, biaya administrasi, lokasi bank dan pelayanan bank terhadap keputusan nasabah dalam memilih bank sebagai tempat menabung baik secara parsial maupun secara global dan 2) menganalisa atribut-atribut yang dianggap penting dan paling memiliki pengaruh terhadap keputusan nasabah dalam memilih bank.

\section{REVIEW LITERATUR DAN HIPOTESIS}

\section{Landasan Teori}

1. ATM (Anjungan Tunai Mandiri)

ATM (Automatic Teller Machine) adalah mesin yang digunakan untuk menggantikan tugas teller pada sebuah bank Dalam bahasa Indonesia ATM adalah singkatan dari Anjungan Tunai mandiri. Dalam skripsi ini penulis 
khusus membahas ATM dan pelayanannya. Pelayanan ATM adalah pelayanan transaksi perbankan yang dilakukan melalui mesin ATM selama 24 jam yang meliputi penarikan tunai, informasi saldo rekening tabungan, setoran tunai (melalui mesin CDM ), pembayaran tagihan, melakukan berbagai jenis pembelian dan pembayaran tagihan tanpa harus datang ke kantor cabang dan terikat waktu.

2. Bunga Bank

Bunga bank dapat diartikan sebagai balas jasa yang diberikan oleh bank yang berdasarkan prinsip konvensional kepada nasabah yang membeli atau menjual produknya. Bunga bagi bank juga dapat diartikan sebagai harga yang harus dibayar kepada nasabah (yang memiliki simpanan) dan harus dibayar oleh nasabah kepada bank (nasabah yang memperoleh pinjaman) (Kasmir, 2010).

\section{Biaya Administrasi Bank}

Biaya administrasi adalah biaya yang diminta oleh pihak bank kepada nasabahnya sebagai balas jasa atas pengelolaan rekening atau tabungan miliknya dan biaya-biaya jasa lainnya. Biaya administrasi setiap bank berbeda-beda, karena biaya administrasi ditentukan sendiri oleh masing-masing bank. Seperti halnya bunga, biaya administrasi juga merupakan harga yang diberikan oleh bank terhadap jasa yang diberikan (Kasmir, 2010).

\section{Lokasi}

Lokasi mempunyai dampak strategis karena menentukan daya saing perusahaan dalam hal kapasitas, proses, fleksibilitas dan biaya, serta kualitas kerja, kontak pelanggan, dan citra perusahaan. Bagi perusahaan non bank penetuan lokasi biasanya digunakan untuk lokasi pabrik atau gudang atau cabang, sedangkan penentuan lokasi bagi industri perbankan lebih ditekankan pada lokasi cabang (Kasmir, 2010).

5. Pelayanan

Pelayanan adalah suatu kegiatan atau urutan kegiatan yang terjadi dalam interaksi langsung antara seseorang dengan orang lain atau mesin secara fisik, dan menyediakan kepuasan pelanggan. Dalam Kamus Besar Bahasa Indonesia dijelaskan pelayanan sebagai usaha melayani kebutuhan orang lain.

6. Keputusan Konsumen (Nasabah)

Menurut Amirulloh (2002)
dikutip dalam Irawan (2009)
pengambilan keputusan merupakan
suatu proses penilaian dan pemilihan
dari berbagai alternatif sesuai dengan
kepentingan-kepentingan tertentu
dengan menetapkan suatu pilihan yang
dianggap paling menguntungkan.

\section{Penelitian Terdahulu}

Menurut penelitian Nurdiana (2008), menunjukkan bahwa dalam memilih bank, preferensi tertinggi hingga terendah adalah fasilitas ATM, kepuasan terhadap fasilitas pelayan customer, suku bunga, biaya administrasi dan CAR (Capital Adequacy Ratio). Dalam melakukan pemilihan bank sebagai tempat menabung diperoleh alternatif yang paling tepat berdasarkan tingkat preferensi tertinggi yaitu Bank BCA dengan persentase 38,7 \%, bank Mandiri dengan persentase $33,7 \%$, dan bank BNI dengan persentase $27,6 \%$.

Menurut Irawan (2009), menunjukkan bahwa faktor minat (psikologis dan rasionalis) yang terdiri dari variabel motivasi, belajar, sikap, persepsi, dan tingkat keuntungan nisbah dan perhitungan bisnis mempunyai hubungan yang kuat dan pengaruh secara signifikan terhadap keputusan nasabah menabung. Faktor minat menjadi hal yang paling dipertimbangkan oleh nasabah dalam keputusan menabung di bank syariah. 


\section{Hipotesis}

H1: Diduga pelayanan mempengaruhi keputusan konsumen dalam memilih bank.

H2: Diduga lokasi bank mempengaruhi keputusan konsumen dalam memilih bank.

H3: Diduga multiguna dan jaringan ATM mempengaruhi keputusan konsumen dalam memilih bank.

H4: Diduga Bunga mempengaruhi keputusan konsumen dalam memilih bank.

H5: Diduga biaya administrasi mempengaruhi keputusan konsumen dalam memilih bank.

H6: Diduga multiguna dan jaringan ATM, bunga, biaya administrasi, lokasi bank dan pelayanan mempengaruhi keputusan konsumen dalam memilih bank.

\section{METODE PENELITIAN}

\section{Populasi dan Sampel}

Populasi adalah wilayah generalisasi yang terdiri atas: obyek/subyek yang mempunyai kualitas dan karakteristik tertentu yang ditetapkan oleh peneliti untuk dipelajari dan kemudian ditarik kesimpulannya (Sugiyono, 2010). Populasi dari penelitian ini adalah masyarakat yang berada di Kota Yogyakarta yang sudah punya rekening tabungan di bank konvensional atau bank umum, dengan berbagai macam profesinya.

Dalam penelitian ini, teknik pengambilan sampel yang dilakukan penulis menggunakan teknik purposive sampling yaitu teknik penentuan sampel dengan pertimbangan tertentu (Sugiyono, 2010). Dimana sampel penelitian adalah orang dengan kriteria harus memiliki rekening tabungan di bank konvensional dengan usia antara 13 sampai dengan 60 tahun.

\section{Definisi Operasional}

1. Variabel Independen

a. ATM (Anjungan Tunai Mandiri)

ATM (Automatic Teller

Machine) adalah mesin yang digunakan untuk menggantikan tugas teller pada sebuah bank Dalam bahasa Indonesia ATM adalah singkatan dari Anjungan Tunai mandiri. Dalam skripsi ini penulis khusus membahas ATM dan pelayanannya. Pelayanan ATM adalah pelayanan transaksi perbankan yang dilakukan melalui mesin ATM selama 24 jam yang meliputi penarikan tunai, informasi saldo rekening tabungan, setoran tunai (melalui mesin CDM ), pembayaran tagihan, melakukan berbagai jenis pembelian dan pembayaran tagihan tanpa harus datang ke kantor cabang dan terikat waktu.

b. Bunga Bank

Bunga bank dapat diartikan sebagai balas jasa yang diberikan oleh bank yang berdasarkan prinsip konvensional kepada nasabah yang membeli atau menjual produknya. Bunga bagi bank juga dapat diartikan sebagai harga yang harus dibayar kepada nasabah (yang memiliki simpanan) dan harus dibayar oleh nasabah kepada bank (nasabah yang memperoleh pinjaman) (Kasmir, 2010).

c. Biaya Administrasi Bank

Biaya administrasi adalah biaya yang diminta oleh pihak bank kepada nasabahnya sebagai balas jasa atas pengelolaan rekening atau tabungan miliknya dan biaya-biaya jasa lainnya. Biaya administrasi setiap bank berbeda-beda, karena biaya administrasi ditentukan sendiri oleh masing-masing bank. Seperti halnya bunga, biaya administrasi juga merupakan harga yang diberikan oleh bank terhadap jasa yang diberikan (Kasmir, 2010). 


\section{d. Lokasi}

Lokasi mempunyai dampak strategis karena menentukan daya saing perusahaan dalam hal kapasitas, proses, fleksibilitas dan biaya, serta kualitas kerja, kontak pelanggan, dan citra perusahaan. Bagi perusahaan non bank penetuan lokasi biasanya digunakan untuk lokasi pabrik atau gudang atau cabang, sedangkan penentuan lokasi bagi industri perbankan lebih ditekankan pada lokasi cabang (Kasmir, 2010).

e. Pelayanan

Pelayanan adalah suatu kegiatan atau urutan kegiatan yang terjadi dalam interaksi langsung antara seseorang dengan orang lain atau mesin secara fisik, dan menyediakan kepuasan pelanggan. Dalam Kamus Besar Bahasa Indonesia dijelaskan pelayanan sebagai usaha melayani kebutuhan orang lain.

f. Variabel Dependen

Variabel dependen (Y) yang digunakan dalam penelitian ini adalah Keputusan Konsumen (Nasabah). Menurut Amirulloh (2002) dikutip dalam Irawan (2009) pengambilan keputusan merupakan suatu proses penilaian dan pemilihan dari berbagai alternatif sesuai dengan kepentingankepentingan tertentu dengan menetapkan suatu pilihan yang dianggap paling menguntungkan.

\section{Uji Instrumen}

\section{Uji Validitas}

Validitas adalah uji yang menunjukkan sejauh mana suatu alat pengukuran itu mengukur apa yang ingin diukur. Dalam pengukuran ini menggunakan Product moment Pearson Correlatif melalui program SPSS. Menurut Umar (2000) untuk mengetahui valid tidaknya variabel yang akan diuji, hasil korelasi dibandingkan dengan angka kritik tabel korelasi dengan taraf signifikansi $1 \%$ atau 5\%. Jika angka korelasi dari hasil perhitungan dibanding angka kritik maka butir pertanyaan dinyatakan valid dan signifikan.

\section{Uji Reliabilitas}

Reliabilitas adalah suatu nilai yang menunjukkan konsistensi suatu alat ukur di dalam mengukur gejala yang sama. Jadi, uji reliabilitas adalah untuk mengetahui sejauh mana suatu pengukuran dapat dipercaya. Reliabilitas menunjukkan konsistensi suatu alat pengukuran didalam mengukur gejala yang sama (Singarimbun, 2011). Pengujian ini menggunakan Cronbach's Alpha dimana Alpha pada output merupakan $\mathrm{r}$ hasil sedangkan $\mathrm{r}$ Alpha sebesar 5\%. Jika nilai Cronbach's Alpha > r tabel maka dinyatakan reliable.

\section{Teknik Analisis Data}

1. Analisis Regresi Berganda

Regresi berganda yaitu untuk menganalisis seberapa besar pengaruh antara beberapa variabel independen. Bentuk umum persamaan regresi berganda adalah sebagai berikut :

$\mathrm{Y}=\alpha+\beta 1 \mathrm{X} 1+\beta 2 \mathrm{X} 2+\beta 3 \mathrm{X} 3+\beta 4 \mathrm{X} 4+$ B5X5

Dimana :

Y : keputusan Konsumen

$\alpha$ : konstanta regresi berganda

$\beta$ : koefisien regresi parsial

$\mathrm{X} 1$ : Pelayanan

X2 : Lokasi Bank

X3 : Multiguna dan Jaringan ATM

X4 : Bunga Bank

X5 : Biaya Administrasi 


\section{Uji Hipotesis}

1. Uji Parsial (Uji T)

Uji instrumen digunakan untuk menguji apakah masingmasing variabel bebas berpengaruh atau tidak terhadap variabel terikat, menggunakan uji masing-masing koefisien regresi mempunyai pengaruh yang bermakna atau tidak terhadap variabel terikat Sugiyono (2005). Karena ada kemungkinan secara bersama-sama variabel bebas berpengaruh nyata terhadap variabel terikat, namun secara individu atau parsial belum tentu berpengaruh nyata terhadap variabel terikat.

Dalam pengujian ini digunakan taraf signifikansi sebesar $5 \%$ dan derajat kebebasan (d.f) $=\mathrm{n}-\mathrm{k}$, dapat diketahui dari hasil perhitungan komputer program SPSS. Kesimpulan yang diambil adalah Jika $\mathrm{t}$ hitung $>\mathrm{t}$ tabel maka Ho ditolak, sebaliknya Jika t hitung < t tabel maka Ho diterima.

\section{Uji Simultan (Uji F)}

Uji instrumen yang digunakan untuk mengetahui pengaruh variabel independen secara bersama-sama terhadap variabel dependen. Menggunakan taraf signifikasi $5 \%$, apabila probabilitas dari variabelvariabel independen kurang dari 0,05, maka dapat disimpulkan bahwa variabel independen secara bersama-sama berpengaruh terhadap variabel dependen.

\section{Uji Koefisien Determinasi}

Koefisien determinasi persamaan regresi berguna untuk mengetahui besarnya persentase pengaruh/ hubungan semua variabel independen terhadap nilai variabel dependen. Besarnya koefisien deterrminasi dari 0 sampai dengan 1.

\section{HASIL PENELITIAN DAN PEMBAHASAN}

\section{Hasil Analisis Responden}

Identitas Responden Berdasarkan Bank

\begin{tabular}{|ll|r|r|r|r|}
\hline & & & & Cumulative \\
& Frequency & Percent & Valid Percent & Percent \\
\hline Valid & BNI & 3.8 & 6.7 & 6.7 \\
& 24 & 22.6 & 40.0 & 46.7 \\
& BRI & 16 & 15.1 & 26.7 & 73.3 \\
BCA & 9 & 8.5 & 15.0 & 88.3 \\
Bank Mandiri & 7 & 6.6 & 11.7 & 100.0 \\
Bank Lain & 60 & 56.6 & 100.0 & \\
Total & & & & \\
\hline
\end{tabular}

Dari tabel di atas, dapat diketahui jumlah responden yang menabung di Bank BRI 24 orang atau sebesar 40\%, BCA 16 orang atausebesar 26,7\%, Bank Mandiri 9 orang atau sebesar $15 \%$, Bank Lain 7 orang atau sebesar $11,7 \%$, dan BNI 4 orang atau sebesar $6,7 \%$. Hal ini menunjukkan bahwa dari responden sebanyak 60 orang kebanyakan menabung di Bank BRI yaitu sebanyak 24 orang atau sebesar $40 \%$.

Identitas Responden Berdasarkan Jenis

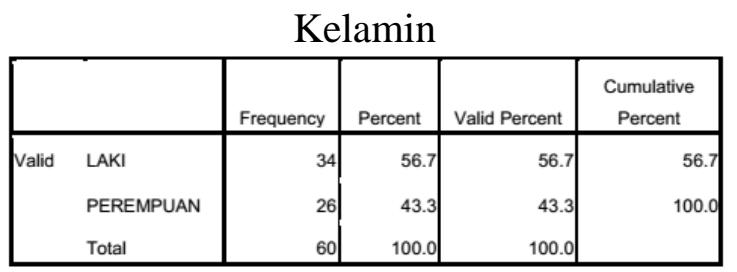

Dari tabel diatas, diketahui bahwa dari 60 responden yang berjenis kelamin laki-laki sebanyak 34 orang atau sebesar $56,7 \%$. Sedangkan responden yang berjenis kelamin perempuan sebanyak 26 orang atau sebesar 43,3\%. Hal ini menunjukkan dari 60 orang responden yang diteliti berjenis kelamin laki-laki. 
Identitas Responden Berdasarkan Tingkat Usia

\begin{tabular}{|c|c|c|c|c|c|}
\hline & & Frequency & Percent & Valid Percent & $\begin{array}{c}\text { Cumulative } \\
\text { Percent } \\
\end{array}$ \\
\hline \multirow[t]{6}{*}{ Valid } & $1-20$ tahun & 5 & 4.7 & 8.3 & 8.3 \\
\hline & $21-30$ tahun & 35 & 33.0 & 58.3 & 66.7 \\
\hline & $31-40$ tahun & 16 & 15.1 & 26.7 & 93.3 \\
\hline & $41-50$ tahun & 3 & 2.8 & 5.0 & 98.3 \\
\hline & $>50$ tahun & 1 & .9 & 1.7 & 100.0 \\
\hline & Total & 60 & 56.6 & 100.0 & \\
\hline
\end{tabular}

Berdasarkan tabel diatas, diketahui bahwa responden berusia $\leq 20$ tahun sebanyak 5 orang atau sebesar $8,3 \%$, usia antara 21-30 tahun sebanyak 35 orang atau sebesar 58,3\%, usia antara 31-40 tahun sebanyak 16 orang atau sebesar $26,7 \%$, usia antara 41-50 tahun sebanyak 3 orang atau sebesar 5\%, dan usia > 50 tahun sebanyak 1 orang atau sebesar $1,7 \%$. Dengan demikian, dari 60 responden yang diteliti usia antara 21-30 tahun adalah yang paling banyak memiliki rekening di Bank yaitu sebanyak 35 orang atau sebesar $58,3 \%$.

Identitas Responden Berdasarkan Status

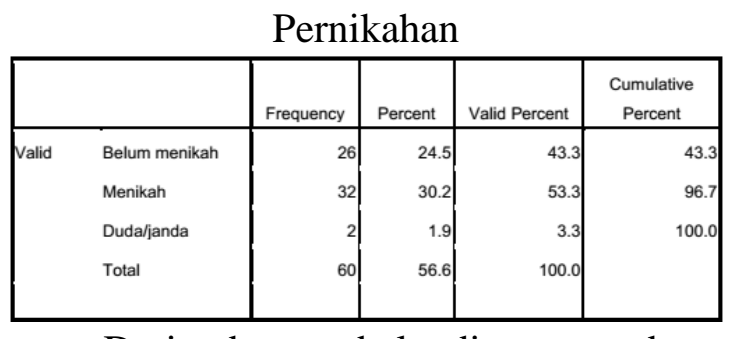

Dari data tabel di atas, dapat diketahui bahwa dari responden yang diteliti sebanyak 32 orang atau sebesar $53,3 \%$ berstatus menikah, sebanyak 26 orang atau sebesar $43,3 \%$ berstatus belum menikah, dan sebanyak 2 orang atau sebesar 3,3\% berstatus Duda/janda. Dari hal tersebut diatas menunjukkan bahwa dari responden yang diteliti sebagaian besar berstatus menikah, sebanyak 32 orang atau $53,3 \%$.
Identitas Responden Berdasarkan Tingkat Pendidikan

\begin{tabular}{|c|c|c|c|c|c|}
\hline & & Frequency & Percent & Valid Percent & $\begin{array}{c}\text { Cumulative } \\
\text { Percent }\end{array}$ \\
\hline \multirow[t]{6}{*}{ Valid } & SLTP & & & 1.7 & 1.7 \\
\hline & SLTA & 42 & 39.6 & 70.0 & 71.7 \\
\hline & DIPLOMA & 6 & 5.7 & 10.0 & 81.7 \\
\hline & SARJANA & 10 & 9.4 & 16.7 & 98.3 \\
\hline & PASCA SARJANA & 1 & s. & 1.7 & 100.0 \\
\hline & Total & 60 & 56.6 & 100.0 & \\
\hline
\end{tabular}

Dari tabel di bawah, diketahui bahwa dari 60 responden yang diteliti sebanyak 1 orang atau $1,7 \%$ berpendidikan SLTP, sebanyak 42 orang atau sebesar $70 \%$ berpendidikan SLTA, sebanyak 6 orang atau sebesar $10 \%$ berpendidikan Diploma, sebanyak 10 orang atau sebesar 16,7\% berpendidikan Sarjana, dan 1 orang atau sebesar $1,7 \%$ berpendidikan Pasca sarjana. Dari data di atas menunjukkan bahwa responden yang di teliti sebagaian besar berpendidikan SLTA yaitu sebanyak 42 orang atau sebesar $70 \%$.

Identitas Responden Berdasarkan Pekerjaan

\begin{tabular}{|ll|r|r|r|r|}
\hline & Frequency & Percent & Valid Percent & $\begin{array}{c}\text { Cumulative } \\
\text { Percent }\end{array}$ \\
\hline Valid & Pelajar & 4 & 3.8 & 6.7 & 6.7 \\
& PNS & 1 & .9 & 1.7 & 8.3 \\
SWASTA & 47 & 44.3 & 78.3 & 86.7 \\
WIRASWASTA & 5 & 4.7 & 8.3 & 95.0 \\
PENSIUNAN & 1 & .9 & 1.7 & 96.7 \\
IBU RUMAH TANGGA & 1 & .9 & 1.7 & 98.3 \\
Lainnya & 1 & .9 & 1.7 & 100.0 \\
Total & 60 & 56.6 & 100.0 & \\
\hline
\end{tabular}

Dari tabel di bawah, dapat diketahui bahwa responden yang diteliti sebanyak 4 orang atau $6,7 \%$ berstatus pelajar, 1 orang atau sebesar $1,7 \%$ berstatus Pegawai Negeri Sipil, sebanyak 47 orang atau sebesar 78,3\% berstatus karyawan swasta, sebanyak 5 orang atau $8,3 \%$ berstatus wiraswasta, 1 orang atau sebesar 1,7\% berstatus pensiunan, 1 orang atau sebesar $1,7 \%$ berstatus ibu rumah tangga, dan 1 orang atau sebesar $1,7 \%$ memiliki pekerjaan lainnya. Dari data di atas menunjukkan bahwa responden yang diteliti sebagaian besar merupakan 
karyawan swasta yaitu sebanyak 47 orang atau sebesar $78,3 \%$.

Identitas Responden Berdasarkan Tingkat Pendapatan

\begin{tabular}{|c|c|c|c|c|c|}
\hline & & Frequency & Percent & Valid Percent & $\begin{array}{l}\text { Cumulative } \\
\text { Percent }\end{array}$ \\
\hline \multirow[t]{5}{*}{ Valid } & $<1 \mathrm{Jt}$ & 10 & 9.4 & 16.7 & 16.7 \\
\hline & $1 \mathrm{Jt}-5 \mathrm{Jt}$ & 45 & 42.5 & 75.0 & 91.7 \\
\hline & $5 \mathrm{Jt}-10 \mathrm{Jt}$ & 4 & 3.8 & 6.7 & 98.3 \\
\hline & $10 \mathrm{Jt}-50 \mathrm{Jt}$ & 1 & .9 & 1.7 & 100.0 \\
\hline & Total & 60 & 56.6 & 100.0 & \\
\hline
\end{tabular}

Dari data tabel di atas, diketahui bahwa 60 orang responden yang diteliti sebanyak 10 orang atau $16,7 \%$ mempunyai penghasilan < Rp 1.000.000/bulan, sebanyak 45 orang atau sebesar $75 \%$ mempunyai penghasilan antara $\mathrm{Rp}$ 1.000.000-Rp 5.000.000, sebanyak 4 orang atau sebesar $6,7 \%$ mempunyai penghasilan antara $\mathrm{Rp} \quad 5.000 .000-\mathrm{Rp}$ 10.000.000, sebanyak 1 orang atau sebesar 1,7\% mempunyai penghasilan antara $\mathrm{Rp}$ 10.000.000-Rp 50.000.000,-. Hal ini menunjukkan, dari semua responden yang diteliti, sebagian besarberpenghasilan antara Rp 1.000.000 - Rp 5.000.000 yaitu sebanyak 45 orang atau sebesar $75 \%$.

Identitas Responden Berdasarkan Tingkat Pengeluaran Tiap Bulan

\begin{tabular}{|c|c|c|c|c|c|}
\hline & & Frequency & Percent & Valid Percent & $\begin{array}{c}\text { Cumulative } \\
\text { Percent }\end{array}$ \\
\hline \multirow[t]{4}{*}{ Valid } & $<1 \mathrm{Jt}$ & 16 & 15.1 & 26.7 & 26.7 \\
\hline & $1 \mathrm{Jt}-5 \mathrm{Jt}$ & 40 & 37.7 & 66.7 & 93.3 \\
\hline & $5 \mathrm{Jt}-10 \mathrm{Jt}$ & 4 & 3.8 & 6.7 & 100.0 \\
\hline & Total & 60 & 56.6 & 100.0 & \\
\hline
\end{tabular}

Berdasarkan tabel di atas, dapat diketahui bahwa dari 60 responden yang diteliti sebanyak 16 orang atau sebesar 26,7\% memiliki pengeluaran kurang dari Rp 1.000.000,-/bulan, sebanyak 40 orang atau sebesar $66,7 \%$ memiliki pengeluaran antara Rp 1.000.000,- s/d Rp 5.000.000,tiap bulan, dan sebanyak 4 orang atau sebesar $6,7 \%$ memiliki pengeluran antara Rp 5.000.000,- s/d Rp Rp 10.000.000,- tiap bulan. Dari penjelasan diatas menunjukkan bahwa sebagian besar reponden yang diteliti memiliki pengeluaran sebesar Rp 1.000.000,- s/d Rp 5.000 .000 ,-tiap bulan, yaitu sebanyak 40 orang atau sebesar $66,7 \%$.

Identitas Responden Berdasarkan Lama Menjadi Nasabah

\begin{tabular}{|c|c|c|c|c|c|}
\hline & & Frequency & Percent & Valid Percent & $\begin{array}{c}\text { Cumulative } \\
\text { Percent }\end{array}$ \\
\hline \multirow[t]{5}{*}{ Valid } & $<1$ tahun & 14 & 13.2 & 23.3 & 23.3 \\
\hline & $1-3$ tahun & 25 & 23.6 & 41.7 & 65.0 \\
\hline & $4-10$ tahun & 16 & 15.1 & 26.7 & 91.7 \\
\hline & $>10$ tahun & 5 & 4.7 & 8.3 & 100.0 \\
\hline & Total & 60 & 56.6 & 100.0 & \\
\hline
\end{tabular}

Dari tabel 4.9 di atas, diketahui bahwa jumlah responden yang menjadi nasabah kurang dari 1 tahun sebanyak 14 orang atau sebesar 23,3\%, yang menjadi nasabah antara $1-3$ tahun sebanyak 25 orang atau sebesar $41,7 \%$, yang menjadi nasabah antara $4-10$ tahun sebanyak 16 orang atau sebesar $26,7 \%$ dan yang menjadi nasabah selama lebih dari 10 tahun sebanyak 5 orang sebesar 8,3\%. Hal ini berarti menunjukkan bahwa dari 60 orang responden yang diteliti kebanyakan sudah menjadi nasabah selama 1 - 3 tahun yaitu sebanyak 25 orang atau sebesar $41,7 \%$. 


\section{Hasil Penelitian}

1. Hasil Uji Validitas

Hasil Uji Validitas

\begin{tabular}{|c|c|c|c|c|c|}
\hline NO & Variabel & Item & $r_{x y}$ & $\mathrm{r}_{\text {tabel }}$ & Keterangan \\
\hline 1 & Pelayanan $\left(\mathrm{X}_{1}\right)$ & $\begin{array}{l}\text { P1 } \\
\text { P2 } \\
\text { P3 } \\
\text { P4 } \\
\text { P5 } \\
\text { P6 }\end{array}$ & $\begin{array}{l}0,378 \\
0,526 \\
0,653 \\
0,541 \\
0,476 \\
0,407\end{array}$ & $\begin{array}{l}0,361 \\
0,361 \\
0,361 \\
0,361 \\
0,361 \\
0,361\end{array}$ & $\begin{array}{l}\text { Valid } \\
\text { Valid } \\
\text { Valid } \\
\text { Valid } \\
\text { Valid } \\
\text { Valid }\end{array}$ \\
\hline 2 & Lokasi $\left(\mathrm{X}_{2}\right)$ & $\begin{array}{l}\text { P1 } \\
\text { P3 } \\
\text { P4 }\end{array}$ & $\begin{array}{l}0,454 \\
0,520 \\
0,698\end{array}$ & $\begin{array}{l}0,361 \\
0,361 \\
0,361\end{array}$ & $\begin{array}{l}\text { Valid } \\
\text { Valid } \\
\text { Valid }\end{array}$ \\
\hline 3 & \begin{tabular}{|l|} 
Multiguna dan \\
Jaringan ATM $\left(\mathrm{X}_{3}\right)$
\end{tabular} & $\begin{array}{l}\text { P1 } \\
\text { P2 } \\
\text { P3 } \\
\text { P4 }\end{array}$ & $\begin{array}{l}0,651 \\
0,750 \\
0,708 \\
0,367\end{array}$ & $\begin{array}{l}0,361 \\
0,361 \\
0,361 \\
0,361 \\
\end{array}$ & $\begin{array}{l}\text { Valid } \\
\text { Valid } \\
\text { Valid } \\
\text { Valid }\end{array}$ \\
\hline 4 & Bunga Bank $\left(\mathrm{X}_{4}\right)$ & $\begin{array}{l}\text { P1 } \\
\text { P2 } \\
\text { P3 } \\
\text { P4 }\end{array}$ & $\begin{array}{l}0,676 \\
0,729 \\
0,660 \\
0,425\end{array}$ & $\begin{array}{l}0,361 \\
0,361 \\
0,361 \\
0,361\end{array}$ & $\begin{array}{l}\text { Valid } \\
\text { Valid } \\
\text { Valid } \\
\text { Valid }\end{array}$ \\
\hline 5 & $\begin{array}{ll}\text { Biaya } & \text { Administrasi } \\
\left(\mathrm{X}_{5}\right) & \\
\end{array}$ & $\begin{array}{l}\text { P1 } \\
\text { P2 } \\
\text { P3 } \\
\text { P4 }\end{array}$ & $\begin{array}{l}0,781 \\
0,649 \\
0,731 \\
0,596\end{array}$ & $\begin{array}{l}0,361 \\
0,361 \\
0,361 \\
0,361\end{array}$ & $\begin{array}{l}\text { Valid } \\
\text { Valid } \\
\text { Valid } \\
\text { Valid }\end{array}$ \\
\hline 6 & \begin{tabular}{|l} 
Keputusan \\
Menabung $(\mathrm{Y})$
\end{tabular} & $\begin{array}{l}\text { P1 } \\
\text { P4 } \\
\text { P5 }\end{array}$ & $\begin{array}{l}0,460 \\
0,597 \\
0.542\end{array}$ & $\begin{array}{l}0,361 \\
0,361 \\
0,361\end{array}$ & $\begin{array}{l}\text { Valid } \\
\text { Valid } \\
\text { Valid }\end{array}$ \\
\hline
\end{tabular}

Dari tabel di atas $r$ tabel $d f=n-2$, dimana $\mathrm{n}$ adalah jumlah sample maka didapat $\mathrm{df}=30-2=28$, dengan tingkat signifikasi yang telah ditentukan yaitu sebesar 5\% di dapat angka untuk rtabel yaitu 0,361. Untuk r xy (r hitung) dari tiap item dapat dilihat pada kolom Corrected Item Total Correlation. Dalam pengambilan keputusan, jika $r$ hitung lebih besar dari $r$ tabel dan bernilai positif maka pertanyaan atau indikator tersebut dinyatakan valid. Di dapat $r$ hitung untuk semua pertanyaan bertanda positif dan lebih besar dari $\mathrm{r}$ tabel $(0,361)$, sehingga semua bisa dikatakan valid.

2. Hasil Uji Reliabilitas

Hasil Uji Reliabilitas Pelayanan, Lokasi Bank, Multiguna Jaringan ATM, Bunga Bank, dan Biaya administrasi terhadap Keputusan Menabung

\begin{tabular}{|l|c|c|c|}
\hline \multicolumn{1}{|c|}{ Variabel } & $\alpha$ (alpha) & $\alpha$ (alpha standar) & Keterangan \\
\hline Pelayanan $\left(\mathrm{X}_{1}\right)$ & 0,745 & 0,60 & Reliabel \\
\hline Lokasi $\left(\mathrm{X}_{2}\right)$ & 0,790 & 0,60 & Reliabel \\
\hline $\begin{array}{l}\text { Multiguna Dan } \\
\text { Jaringan ATM }\left(\mathrm{X}_{3}\right)\end{array}$ & 0,785 & 0,60 & Reliabel \\
\hline Bunga Bank $\left(\mathrm{X}_{4}\right)$ & 0,798 & 0,60 & Reliabel \\
\hline $\begin{array}{l}\text { Biaya administrasi } \\
\left(\mathrm{X}_{5}\right)\end{array}$ & 0,843 & 0,60 & Reliabel \\
\hline $\begin{array}{l}\text { Keputusan Menabung } \\
(\mathrm{Y})\end{array}$ & 0,673 & 0,60 & Reliabel \\
\hline
\end{tabular}

Dari tabel di atas semua cronbach alpha masing-masing variabel menunjukkan lebih besar dari 0,60 yaitu Pelayanan (X1) sebesar $\alpha=0,745$,
Lokasi (X2) sebesar $\alpha=0,790$, Multiguna Jaringan ATM (X3) sebesar $\alpha=0,785$, Bunga Bank (X4) sebesar $\alpha=$ 0,798, Biaya Administrasi (X5) sebesar $\alpha=0,843$, dan untuk Pelayanan (Y) sebesar $\alpha=0,673$. Dari semua data di atas dapat ditarik kesimpulan bahwa semua variabel penelitian adalah variabel.

3. Hasil Uji Regresi Linier Berganda Hasil Analisis Regresi Berganda

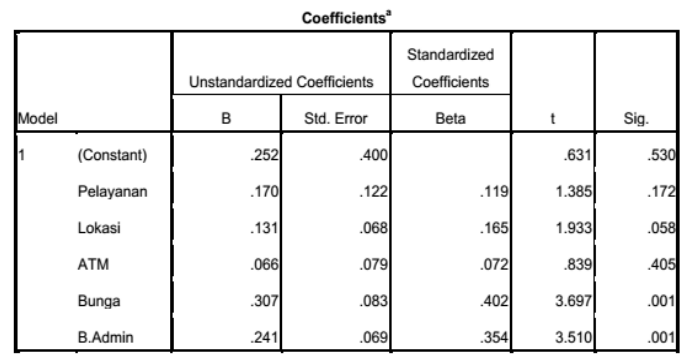

Berdasarkan analisis regresi berganda di atas, dapat dibuat persamaan regresi berganda sebagai berikut:

Y: $0,252+0,170 \mathrm{X} 1+0,131 \mathrm{X} 2+$ $0,066 \mathrm{X} 3+0,307 \mathrm{X} 4+0,241 \mathrm{X} 5$

Persamaan di atas mengandung pengertian sebagai berikut :

a. Nilai konstanta (a) sebesar 0,252

Nilai konstanta sebesar 0,252 tersebut menyatakan jika tidak ada Pelayanan, Lokasi Bank, Multiguna Jaringan ATM, Bunga dan Biaya Administrasi maka Keputusan Menabung sebesar 0,252.

b. Nilai koefisien regresi Pelayanan (X1) sebesar 0,170

Nilai koefisien regresi X1 sebesar 0,170 tersebut menyatakan pengaruh dari X1 terhadap Y apabila besarnya nilai $\mathrm{X}$ lainnya= tetap atau konstan adalah sebesar 0,170. Nilai yang diperoleh tersebut bernilai positif, sehingga apabila terjadi peningkatan Pelayanan sebesar 1 satuan, maka akan meningkatkan Keputusan Menabung sebesar 0,170 satuan.

c. Nilai koefisien regresi Lokasi Bank (X2) sebesar 0,131 
Koefisien regresi sebesar 0,131 menyatakan bahwa pengaruh nilai X2 terhadap Y apabila besarnya vaiabel $X$ lainya $=$ tetap atau konstan adalah sebesar 0,131. Karena yang diperoleh tersebut bernilai positif, maka apabila terjadi peningkatan Lokasi Bank sebesar 1 satuan, maka akan meningkatkan Keputusan Menabung sebesar 0,131 satuan.

d. Nilai koefisien regresi Multiguna dan Jaringan ATM (X3) sebesar 0,066

Koefiesien regresi sebesar 0,066 menyatakan bahwa pengaruh nilai X3 terhadap Y apabila besarnya variabel $X$ lainnya $=$ tetap atau konstan adalah 0,066. Nilai yang diperoleh dari hasil regresi tersebut bernilai positif, sehingga apabila terjadi peningkatan Multiguna Dan Jaringan ATM sebesar 1 satuan, maka akan meningkatkan Keputusan Menabung sebesar 0,066 satuan.

e. Nilai koefisien regresi Bunga (X4) sebesar 0,307

Koefisien regresi sebesar 0,307 menyatakan bahwa pengaruh nilai X4 terhadap Y apabila besar variabel $\mathrm{X}$ lainya $=$ tetap atau konstan adalah sebesar 0,307. Nilai yang diperoleh dari hasil regresi tersebut adalah positif, sehingga apabila terjadi peningkatan besarnya Bunga sebesar 1 satuan, maka akan meningkatkan Keputusan Menabung sebesar 0,307 satuan.

f. Nilai koefisien regresi Biaya Administrasi (X5) sebesar 0,241

Koefisien regresi sebesar 0,241 menyatakan bahwa pengaruh nilai X5 terhadap Y apabila besarnya variabel $X$ lainya $=$ tetap atau konstan adalah sebesar 0,241 . Nilai yang diperoleh dari hasil regresi tersebut adalah positif, sehingga apabila terjadi peningkatan Biaya Administrasi sebesar 1 satuan, maka akan meningkatkan Keputusan Menabung sebesar 0,241 satuan.
4. Hasil Uji Parsial (Uji T)

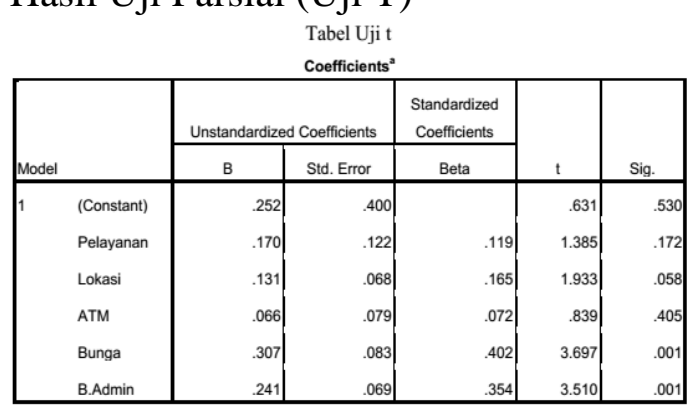

Pada variabel Pelayanan (X1) hasil $t$ hitung dari hasil pengolahan data menggunakan program SPSS 17.0 didapat sebesar 1,385, dan $\mathrm{t}$ tabel adalah 2,0057. Maka H0 diterima karena $\mathrm{t}$ hitung $<\mathrm{t}$ tabel artinya tidak ada pengaruh yang signifikan dari variabel Pelayanan (X1) terhadap variabel Keputusan Menabung (Y) nasabah pada bank di Yogyakarta. Hal ini terjadi karena secara umum semua SOP pelayanan di bank adalah sama, maka calon nasabah jarang mempertimbangkan pelayanan yang diberikan oleh semua pegawai bank.

Pada variabel Lokasi Bank (X2) hasil $\mathrm{t}$ hitung adalah 1,933 dan $\mathrm{t}$ tabel adalah 2,0057, maka H0 diterima karena $\mathrm{t}$ hitung $<\mathrm{t}$ tabel. Artinya, variabel Lokasi Bank (X2) tidak berpengaruh secara signifikan terhadap Keputusan Menabung (Y) nasabah pada bank di Yogyakarta. Hal ini bisa terjadi dikarenakan, sudah adanya fasilitas transportasi dan akomodasi yang baik. Yaitu berupa kendaraan bermotor, sehingga bagi nasabah, lokasi bank yang jauh maupun dekat tidaklah masalah selama masih ditempuh dengan kendaraan. Selain itu jarak lokasi bank dengan kediaman rata-rata maksimal bisa ditempuh selama 30 menit.

Dari variabel Multiguna dan Jaringan ATM (X3) didapat $t$ hitung adalah 0,839 dan t tabel adalah 2,0057 sehingga dapat dinyatakan $\mathrm{H} 0$ diterima karena $\mathrm{t}$ hitung $<\mathrm{t}$ tabel. Artinya variabel Multiguna dan Jaringan ATM (X3) tidak ada pengaruh secara signifikan terhadap variabel Keputusan Menabung (Y) nasabah pada bank di 
Yogyakarta. Hal ini bisa terjadi, salah satunya dikarenakan adanya jaringan ATM Bersama, sehingga bagi nasabah apabila bank yang akan dipilihnya tidak memiliki jaringan ATM yang banyak dan luas, mereka masih bisa menggunakan jaringan ATM Bersama yang dimiliki ATM bank manapun.

Variabel Bunga Bank (X4), setelah olah data menggunakan SPSS 17.0 didapat $t$ hitung 3,697 dan t tabel 2,0057, dari hal tersebut dapat disimpulkan $\mathrm{H} 0$ ditolak karena t hitung $>\mathrm{t}$ tabel. Hal tersebut berarti ada pengaruh yang signifikan dari variabel Bunga bank (X4) terhadap variabel Keputusan Menabung (Y) nasabah pada bank di Yogyakarta.

Pada variabel Biaya Administrasi (X5), hasil t hitungnya adalah 3,510 dan t tabel 2,0057. Dari hal tersebut maka $\mathrm{H} 0$ ditolak karena $\mathrm{t}$ hitung $>\mathrm{t}$ tabel. Artinya ada pengaruh yang signifikan dari variabel Biaya Administrasi (X5) terhadap variabel Keputusan Menabung (Y) nasabah pada bank di Yogyakarta.

5. Hasil Uji Simultan (Uji F)

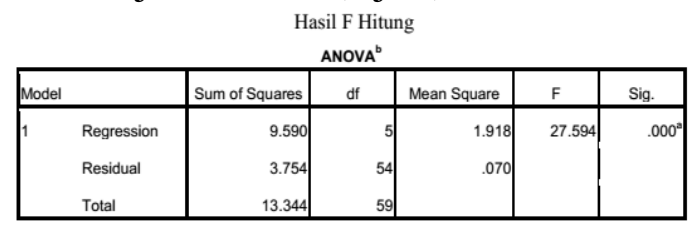

Berdasarkan perhitungan di atas, diperoleh $\mathrm{F}$ hitung sebesar 27,594 dan F tabel sebesar 2,28. Sehingga F hitung > F tabel, maka H0 ditolak. Artinya, dapat disimpulkan bahwa secara bersamasama terdapat pengaruh yang signifikan antara variabel Pelayanan (X1), Lokasi Bank (X2), Multiguna Dan Jaringan ATM (X3), Bunga Bank (X4) dan juga Biaya Administrasi (X5) terhadap variabel Keputusan Menabung Nasabah pada Bank di Kota Yogyakarta.
6. Hasil Uji Koefisien Determinasi Hasil R Square

\begin{tabular}{|c|c|c|c|c|}
\hline \multicolumn{5}{|c|}{ Model Summary ${ }^{b}$} \\
\hline Model & $\mathbf{R}$ & R Square & $\begin{array}{l}\text { Adjusted R } \\
\text { Square }\end{array}$ & $\begin{array}{l}\text { Std. Error of the } \\
\text { Estimate }\end{array}$ \\
\hline 1 & $.848^{\mathrm{a}}$ & .719 & .693 & .26365 \\
\hline
\end{tabular}

Koefisien determinasi persamaan regresi berguna untuk mengetahui besarnya persentase pengaruh/ hubungan semua variabel independen terhadap nilai variabel dependen. Dari hasil olah data dengan menggunakan program SPSS 17.0 didapat koefisien determinasi (R2) sebesar 0,719. Hal ini berarti $71,9 \%$ Keputusan Menabung Nasabah pada Bank di Yogyakarta dapat dijelaskan oleh variabel Pelayanan, Lokasi Bank, Multiguna Dan Jaringan ATM, Bunga Bank, dan Biaya Administrasi. Sedangkan sisanya sebesar 28,1\% dijelaskan oleh sebabsebab lain yang tidak penulis teliti.

\section{Pembahasan}

Berdasarkan penelitian yang penulis lakukan didapat kesimpulan bahwa Pelayanan, Lokasi Bank, Multiguna Dan Jaringan ATM, Bunga Bank, dan Biaya Administrasi mempunyai pengaruh yang positif dan signifikan terhadap Keputusan Nasabah dalam memilih bank secara bersama-sama. Adapun secara parsial variabel Pelayanan, Lokasi Bank, dan Multiguna Jaringan ATM tidak mempunyai pengaruh yang signifikan terhadap Keputusan Nasabah dalam memilih bank, sementara Bunga Bank dan Biaya Administrasi mempunyai pengaruh positif dan signifikan terhadap Keputusan Nasabah dalam memilih bank.

Berdasarkan pengujian semua variabel di atas didapat pengaruh yang positif terhadap keputusan nasabah, sehingga bagi perusahaan/bank dapat melakukan promosi atau pengenalan kepada masyarakat dengan lebih mengedepankan variabel-variabel diatas. Selain itu perlu sebuah terobosan dalam pelayanan baik itu pelayanan oleh pegawai maupun produk bank seperti multiguna 
ATM untuk semua kalangan nasabah, sehingga bisa menjadi salah satu faktor yang dipertimbangkan oleh nasabah dalam memilih bank selain bunga dan biaya administrasi.

Untuk faktor lain yang menurut penulis mempunyai pengaruh terhadap keputusan nasabah dalam memilih bank yang tidak penulis teliti misalnya: pengaruh tingkat penghasilan dan pengeluaran terhadap keputusan nasabah dan lain sebagainya.

\section{KESIMPULAN DAN SARAN}

\section{Kesimpulan}

1. Dari hasil uji $\mathrm{F}$ diperoleh kesimpulan bahwa secara bersama-sama terdapat pengaruh yang positif dan signifikan antar variabel independen yaitu variabel Pelayanan (X1), Lokasi Bank (X2), Multiguna Dan Jaringan ATM (X3), Bunga Bank (X4), dan Biaya Administrasi (X5) terhadap variabel dependen yaitu Keputusan Menabung (Y) karena diperoleh nilai $\mathrm{F}$ hitung $(27,594)>F$ tabel $(2,28)$.Sehingga dengan demikian hipotesis ke enam yang menyatakan bahwa ada pengaruh Multiguna dan Jaringan ATM, Bunga, Biaya Administrasi, Lokasi Bank dan Pelayanan mempengaruhi keputusan konsumen dalam memilih bank, terbukti.

2. Dari hasil uji t diperoleh kesimpulan bahwa secara parsial ada tiga variabel yang tidak berpengaruh terhadap Keputusan nasabah dalam memilih bank yaitu variabel Pelayanan (X1) dengan nilai $\mathrm{t}$ hitung $(1,385)<\mathrm{t}$ tabel (2,0057), Lokasi bank (X2) dengan nilai $\mathrm{t}$ hitung $(1,933)<\mathrm{t}$ tabel $(2,0057)$, Multiguna Dan Jaringan ATM (X3) dengan nilai $\mathrm{t}$ hitung $(0,839)<\mathrm{t}$ tabel $(2,0057)$ dengan demikian hipotesis ke 1,2 dan 3 yang menyatakan ada pengaruh Pelayanan (X1), Lokasi Bank (X2), dan Multiguna Jaringan ATM (X3) terhadap Keputusan Konsumen dalam memilih bank (Y) sebagai tempat menabung di Yogyakarta, tidak terbukti. Masih dari hasil uji t, secara parsial diperoleh dua variabel yang berpengaruh positif dan signifikan terhadap keputusan konsumen/nasabah dalam memilih sebagai tempat menabung di Yogyakarta yaitu variabel Bunga Bank (X4) dengan nilai t hitung $(3,697)>t$ tabel $(2,0057)$ dan variabel Biaya Administrasi (X5) dengan nilai $t$ hitung $(3,510)>t$ tabel $(2,0057)$. Sehingga dengan demikian hipotesis yang keempat yang menyatakan bahwa Bunga mempengaruhi keputusan konsumen/nasabah dalam memilih bank sebagai tempat menabung di Yogyakarta, terbukti. Demikian pula dengan hipotesis yang kelima yang menyatakan bahwa Biaya Administrasi mempengaruhi keputusan konsumen /nasabah dalam memilih bank sebagai tempat menabung di Yogyakarta, terbukti.

\section{Saran}

1. Hasil penelitian menunjukkan adanya pengaruh yang positif variabel Pelayanan, Lokasi Bank, Multiguna Jaringan ATM, Bunga Bank dan Biaya Administrasi terhadap Keputusan nasabah dalam memilih bank sebagai tempat menabung. Dari hal tersebut,bank-bank di Yogyakarta agar dapat meningkatkan promosi yang yang memang lebih mengedepankan informasi tentang bunga serta biaya administrasi disamping juga menyampaikan informasi lainya.

2. Bagi penelitian selanjutnya yang akan melakukan penelitian dengan topik sejenis, disarankan untuk lebih memperbanyak sampel serta mencari variabel-variabel lain selain yang sudah diteliti ini. 


\section{DAFTAR PUSTAKA}

Irawan, Hendi. (2009). Analisis FaktorFaktor yang Mempengaruhi Nasabah Dalam Memutuskan Menabung Di Bank Syariah Mandiri Cabang Malang. Skripsi. Malang: Universitas Negeri Malang.

Kasmir. (2010). Manajemen Perbankan. Edisi 1. Jakarta: PT Raja Grafindo Persada.

Nurdiana, Efi. (2008). Analisis Pemilihan Bank Sebagai Tempat Menabung Dengan Metode Analytical Hierarchy Process. Artikel Jurusan Manajemen Perbankan. Fakultas Ekonomi Universitas Gunadarma Jakarta.

Singarimbun, Masri dan Sofian Effendi. (2011). Metode Penelitian Survei. Jakarta: LP3ES.

Sugiyono. (2005). Memahami Penelitian Kualitatif. Bandung: Alfabeta.

Sugiyono. (2010). Metode Penelitian Pendidikan Pendekatan Kuantitatif, Kualitatif dan $R \& D$. Bandung: Alfabeta.

Umar, Husein. (2000). Metode Penelitian Untuk Skripsi Dan Tesis Bisnis. Jakarta: Raja Grafindo Persada. 